\title{
Gas Phase Far Ultraviolet Photolysis and Radiolysis of Vinyl Chloride*
}

\author{
P. Ausloos, R. E. Rebbert \\ Institute for Materials Research, National Bureau of Standards, Washington, D.C. 20234 \\ M. H. J. Wijnen \\ Hunter College of the City University of New York, New York, N.Y. 10021
}

(November 30, 1972)

\begin{abstract}
Quantum yields of the major products formed in the far ultraviolet photolysis of $\mathrm{CH}_{2} \mathrm{CDCl}\left(\mathrm{C}_{2} \mathrm{H}_{2}\right.$, $\mathrm{C}_{2} \mathrm{HD}, \mathrm{C}_{2} \mathrm{H}_{3} \mathrm{D}, \mathrm{C}_{2} \mathrm{H}_{2} \mathrm{D}_{2}$, and $\left.1,3-\mathrm{C}_{4} \mathrm{H}_{4} \mathrm{D}_{2}\right)$ have been determined at $147 \mathrm{~nm}(8.4 \mathrm{eV}), 123.6 \mathrm{~nm}(10.0 \mathrm{eV})$, and 104.8-106.7 nm (11.6-11.8 eV). The quantum yield of the stable vinyl radicals which can be unambiguously ascribed to the primary process $\left(\mathrm{CH}_{2} \mathrm{CDCl}+h \nu \rightarrow \mathrm{CH}_{2} \mathrm{CD}+\mathrm{Cl}\right)$ is 0.3 and 0.05 at 147 and $123.6 \mathrm{~nm}$, respectively. The sharp decrease in the yield of vinyl radicals with the increase in energy of the incident photon beam is in part attributed to the decomposition of internally excited vinyl radicals to give acetylene as a product. At $147 \mathrm{~nm}$, the combined yield of acetylene plus vinyl radicals is $0.95 \pm 0.05$. At the shorter wavelengths, approximately one acetylene molecule is formed per electronically excited vinyl chloride molecule. It is concluded that the dissociative process: $\mathrm{C}_{2} \mathrm{H}_{3} \mathrm{Cl}^{*} \rightarrow \mathrm{C}_{2} \mathrm{H}_{2}+\mathrm{H}+\mathrm{Cl}$, occurring via a $\mathrm{C}_{2} \mathrm{H}_{3}$ or $\mathrm{C}_{2} \mathrm{H}_{2} \mathrm{Cl}$ intermediate adequately accounts for the reactive neutral species formed at higher photon energies. Isotopic labeling experiments show that the hydrogen atoms are detached from both positions of the parent molecule. Ethylene which is a product over the entire wavelength range is in part formed via the reaction: $\mathrm{H}^{*}+\mathrm{C}_{2} \mathrm{H}_{3} \mathrm{Cl} \rightarrow \mathrm{C}_{2} \mathrm{H}_{4}+\mathrm{Cl}$, where $\mathrm{H}^{*}$ represents a translationally excited hydrogen atom. The $\mathrm{C}_{2} \mathrm{H}_{2} \mathrm{DCl}^{+}$ions formed at 104.8 $-106.7 \mathrm{~nm}$ with a quantum yield of 0.47 do not contribute to the formation of acetylene or vinyl radicals. In the gas phase radiolysis of vinyl chloride, acetylene $(G \sim 1.5)$ is mainly formed in the dissociation of neutral electronically excited vinyl chloride molecules. From this value, we may estimate that the ratio of neutral excited molecules formation to ionization in the radiolysis of vinyl chloride is 0.39 . Vinyl ions, which are also produced $(G \sim 0.28-0.35)$ react mainly by addition to vinyl chloride.
\end{abstract}

Key words: Gas phase; photolysis; quantum yield; radiolysis; vinyl chloride; vinyl radical.

\section{Introduction}

Radiation-induced polymerization of vinyl chloride has been investigated extensively, mainly because vinyl chloride is often used in industrial polymerization processing [1-2]. ${ }^{1}$ In contrast, the fragmentation of excited vinyl chloride monomer molecules formed by photon absorption or electron impact has received little attention [3].

The present study deals with the decomposition of neutral vinyl chloride molecules excited by absorption of photons whose energy $(8.4$ to $11.8 \mathrm{eV})$ brackets the ionization potential of vinyl chloride (I.P. $=9.99 \mathrm{eV}$ ) [4]. Information gained from these photochemical experiments enables us to assess the contribution of neutral excited molecule precursors to the formation of low molecular weight products formed in gas phase radiolysis experiments.

\footnotetext{
${ }^{*}$ Work supported in part by the U.S. Atomic Energy Commission.

1 Figures in brackets indicate the literature references at the end of this paper.
}

\section{Experimental Procedures}

\subsection{Materials}

The vinyl halides used in this study were purified by gas chromatography. The major ions in the $70 \mathrm{eV}$ mass spectrum of the purified $\mathrm{CH}_{2} \mathrm{CDCl}$ were as follows: $\mathrm{C}_{2} \mathrm{H}_{2} \mathrm{DCl}^{+}-39.2$ percent, $\left(\mathrm{C}_{2} \mathrm{HDCl}^{+}+\mathrm{C}_{2} \mathrm{H}_{3} \mathrm{Cl}^{+}\right)$ -2.05 percent, $\mathrm{C}_{2} \mathrm{H}_{2} \mathrm{D}^{+}-32.7$ percent, $\left(\mathrm{C}_{2} \mathrm{H}_{3}^{+}\right.$ $\left.+\mathrm{C}_{2} \mathrm{HD}^{+}\right)-8.4$ percent, $\left(\mathrm{C}_{2} \mathrm{H}_{2}^{+}+\mathrm{C}_{2} \mathrm{D}^{+}\right)-4.2$ percent. The mass spectrum did not show any evidence for the presence of higher deuterium labeled vinyl chloride molecules $\left(\mathrm{C}_{2} \mathrm{HD}_{2} \mathrm{Cl}<0.1 \%\right)$. Mass 27 in the $70 \mathrm{eV}$ mass spectrum can mainly be ascribed to $\mathrm{C}_{2} \mathrm{HD}^{+}$ rather than to $\mathrm{C}_{2} \mathrm{H}_{3}^{+}$in view of the fact that a low electron energy mass spectrum of the $\mathrm{CH}_{2} \mathrm{CDCl}$ material contained less than 2 percent $\mathrm{C}_{2} \mathrm{H}_{3} \mathrm{Cl}$. The $\mathrm{HI}$ and NO were purified by low temperature distillation.

The $200 \mathrm{ml}$ reaction vessel and light sources used in the photochemical experiments have been described in a previous report from this laboratory [5]. The xenon and argon resonance lamps were provided with $\mathrm{LiF}$ windows, while the krypton resonance light source 
was fitted with a $\mathrm{CaF}_{2}$ window transmitting only the $10 \mathrm{eV}$ resonance line. The number of photons transmitted through the $\mathrm{LiF}$ window (diameter: $2.1 \mathrm{~cm}$ ) of the resonance lamps were as follows: xenon, $3 \times 10^{13}$ photon/s (97\% $147 \mathrm{~nm} ; 3 \% 129.5 \mathrm{~nm})$; krypton, 1 to $4 \times 10^{14}$ photon/s; argon, 1 to $4 \times 10^{13}$ photon/s $(45 \%$ $104.8 \mathrm{~nm} ; 55 \% 106.7 \mathrm{~nm})$. Because of polymer formation on the fluoride window, the output of the resonance lamps diminishes from one experiment to the next. At a vinyl chloride pressure of 1 torr, the drop in transmission was most severe when argon resonance radiation was used (30\% after a total output of $4 \times 10^{15}$ photons) and was least pronounced in the xenon resonance experiments ( $1 \%$ after a total output of $4 \times 10^{15}$ photons).

The quantum yields of hydrogen at $147 \mathrm{~nm}$ given in the Results section were based on the yield of $\mathrm{CO}$ produced in the photolysis of $\mathrm{CO}_{2}$ (taking $\Phi(\mathrm{CO})=1$ ) [6]. The quantum yields of the other products were determined by using ethylene (1.5 torr) as a chemical actinometer. The quantum yield of acetylene at 147 and $123.6 \mathrm{~nm}$ was established $[7-8]$ to be $1 \pm 0.05$. At $104.8-$ 106.7, $\Phi\left(\mathrm{C}_{2} \mathrm{H}_{2}\right)$ has been estimated [9] to be $0.75 \pm$ 0.05 . In the present study ethylene offers an advantage as an actinometer in that the product acetylene can be measured on the same gas chromatograph column as that used for analyzing the products formed in the photolysis of the vinyl halides. Because of the drop in transmission of the window occurring during the vinyl halide experiments, actinometry experiments were performed after each argon resonance photolysis experiment. In the case of the xenon resonance experiments, actinometry had to be performed only after every 3 to 5 experiments. Because the ionization potential of vinyl chloride is slightly below $10 \mathrm{eV}$, the drop in transmission during radiation with the 10 and 11.6$11.8 \mathrm{eV}$ photons could also be determined by monitoring the saturation ion current as a function of time. Such ion current measurements concurred with the chemical actinometer determinations. The photoionization quantum yields $\left(\Phi_{+}\right)$given in table 1 are based on the saturation ion currents measured in $\mathrm{NO}$ as a standard $\left(\Phi_{+}(\mathrm{NO})_{123.6}=0.77, \Phi_{+}(\mathrm{NO})_{104.8-106.7}=0.70\right)$ [10]. These measurements were carried out at pressures at which all incident light is absorbed by the vinyl halides ( 0.2 to 1.0 torr). The absorption coefficient of vinyl chloride at $147 \mathrm{~nm}$ is $355 \pm 25 \mathrm{~atm}^{-1} \mathrm{~cm}^{-1}$.

The NBS cobalt-60 gamma-ray source was used for the radiolysis experiments. Cylindrical $100 \mathrm{ml}$ borosilicate glass reaction vessels were provided with break seals. The dose rate was $12.4 \times 10^{19} \mathrm{eV} / \mathrm{g}$-s.

TABLE 1. Photoionization quantum yields $300 \mathrm{~K}$

\begin{tabular}{cc|c}
\hline \hline \multicolumn{2}{c|}{$10 \mathrm{eV}$} & $11.6-11.8 \mathrm{eV}$ \\
\hline $\mathrm{C}_{2} \mathrm{H}_{3} \mathrm{~F}$ & 0.00 & 0.28 \\
$\mathrm{C}_{2} \mathrm{H}_{3} \mathrm{Cl}$ & .037 & .47 \\
$\mathrm{C}_{2} \mathrm{H}_{3} \mathrm{Br}$ & .167 & .61 \\
\hline
\end{tabular}

Product yields in the photolysis experiments are given in terms of quantum yields. The precision estimated from the scatter of the results is \pm 5 percent.
Products observed in the radiolysis experiments are expressed in $G$-values (molecules per $100 \mathrm{eV}$ absorbed). Taking a $W$ - value of $24.7 \mathrm{eV}$ [11] for vinyl chloride, ion pair yields can be obtained by multiplying the $G$ values by 0.247 .

\section{Results}

Acetylene and ethylene are the major hydrocarbon products in all vinyl halide photolysis and radiolysis experiments (tables 2 to 5). 1,3-Butadiene is also produced, but only in the xenon resonance photolysis of pure vinyl chloride could the quantum yield of this product be determined with a better than 10 percent accuracy (table 2). At the shorter wavelengths and in the radiolysis, the yield of butadiene relative to that of acetylene was a factor of 10 less than in the xenon

TABle 2. Photolysis of vinyl halides at $147 \mathrm{~nm}$

\begin{tabular}{|c|c|c|c|c|c|}
\hline \multirow[t]{2}{*}{$\begin{array}{c}\mathrm{C}_{2} \mathrm{H}_{3} \mathrm{X} \\
\text { pressure }\end{array}$} & \multirow[t]{2}{*}{$\begin{array}{l}\text { Additive } \\
\text { (Torr) }^{\mathrm{a}}\end{array}$} & \multirow{2}{*}{$\begin{array}{l}\text { Photons } \\
\text { absorbed } \\
\times 10^{15}\end{array}$} & $\begin{array}{l}\text { Acety- } \\
\text { lene }\end{array}$ & Ethylene & $\begin{array}{l}\text { 1,3-Buta- } \\
\text { diene }\end{array}$ \\
\hline & & & \multicolumn{3}{|c|}{ Quantum yields } \\
\hline \multicolumn{6}{|l|}{$\begin{array}{c}\text { Vinyl } \\
\text { chloride }\end{array}$} \\
\hline 0.2 & & 20 & 0.59 & 0.113 & n.d. \\
\hline 1.0 & & 10 & .60 & .084 & 0.17 \\
\hline 1.0 & & 20 & .59 & .097 & .12 \\
\hline 1.0 & $\mathrm{HI}-0.1$ & 20 & .59 & .377 & .00 \\
\hline 5.3 & n.......... & 16 & .59 & .071 & .16 \\
\hline 5.3 & & 60 & .58 & .070 & n.d. \\
\hline 5.3 & $\mathrm{He}^{-100}$ & 60 & .57 & .008 & n.d. \\
\hline 5.3 & $\mathrm{O}_{2}-0.1$ & 20 & .58 & .065 & .00 \\
\hline 5.3 & $\mathrm{HI}-.01$ & 10 & .57 & .368 & .00 \\
\hline 5.3 & $\mathrm{HI}-.04$ & 10 & .59 & .388 & .00 \\
\hline 5.3 & $\mathrm{HI}-.10$ & 10 & .59 & .385 & .00 \\
\hline 5.3 & $\mathrm{HI}-.50$ & 10 & .58 & .394 & .00 \\
\hline 5.3 & HI-5.6 & 10 & .60 & .384 & .00 \\
\hline 22.6 & & 20 & .58 & .070 & n.d. \\
\hline 22.6 & $\mathrm{HI}-2.0$ & 20 & .59 & .385 & .00 \\
\hline \multicolumn{6}{|l|}{$\begin{array}{c}\text { Vinyl } \\
\text { bromide }\end{array}$} \\
\hline 5.3 & & 20 & .89 & .140 & $<.02$ \\
\hline 5.3 & $\mathrm{HI}-0.5$ & 20 & .91 & .186 & .00 \\
\hline 44.4 & & 20 & .91 & .125 & n.d. \\
\hline
\end{tabular}

a 1 Torr $=1.33 \times 10^{2}$ newton $/$ meter $^{2}$.

resonance experiments and therefore no attempt was made to obtain quantitative measurements of this product. The quantum yield of 1,3-butadiene in the xenon resonance photolysis of pure vinyl chloride (1 torr) diminishes nearly 30 percent when the number of photons absorbed by vinyl chloride in the course of one experiment is increased from 10 to $20 \times 10^{15}$ photons (table 2). $\mathrm{C}_{2} \mathrm{HCl}$ is observed as a product in the photolysis of vinyl chloride, with quantum yields of $0.012 \pm 0.002$ and $0.02 \pm 0.005$ at 147 and $123.6 \mathrm{~nm}$ respectively. Addition of $\mathrm{O}_{2}$ or $\mathrm{HI}$ to vinyl chloride did not alter these quantum yields. In the radiolysis, $G\left(\mathrm{C}_{2} \mathrm{HCl}\right)=0.045 \pm 0.005$.

The quantum yields of $\mathrm{H}_{2}$ and $\mathrm{HD}$ in the $147 \mathrm{~nm}$ photolysis of $\mathrm{CH}_{2} \mathrm{CDCl}$ were $0.047 \pm 0.005$ and $0.01 \pm 0.002$ respectively. In the photolysis of $\mathrm{C}_{2} \mathrm{H}_{3} \mathrm{~F}$ 
at $147 \mathrm{~nm}, \Phi\left(\mathrm{H}_{2}\right)$ was determined to be $0.079 \pm 0.01$. These hydrogen quantum yield determinations were within experimental error, independent of pressure over the range 5 to 50 torr. Quantum yields of hydrogen could not be determined at shorter wavelengths because of the sharp drop in transmission of the LiF window as a function of radiation time.

\section{Discussion}

\subsection{Photolysis in the Subionization Region}

It is firmly established [3] that electronically excited vinyl chloride molecules produced in the vapor phase photolysis over the wavelength range $\sim 190-220 \mathrm{~nm}$ dissociate by cleavage of the $\mathrm{C}-\mathrm{Cl}$ bond

$$
\mathrm{C}_{2} \mathrm{H}_{3} \mathrm{Cl} \rightarrow \mathrm{C}_{2} \mathrm{H}_{3}+\mathrm{Cl}
$$

and by the molecular elimination of $\mathrm{HCl}$

$$
\mathrm{C}_{2} \mathrm{H}_{3} \mathrm{Cl} \rightarrow \mathrm{C}_{2} \mathrm{H}_{2}+\mathrm{HCl} .
$$

$\Phi_{1} / \Phi_{2}$ was found to be 1.4 , independent of pressure ( 2 to 600 torr) and temperature $\left(-78\right.$ to $40^{\circ} \mathrm{C}$ ).

At the shorter wavelength $(147 \mathrm{~nm})$ used in the present study the occurrence of process 1 is indicated by the presence of 1,3-butadiene as a significant procuct (table 2) and the enhanced quantum yield of ethylene when $\mathrm{HI}$ is added as a free radical scavenger to vinyl chloride. The independence of $\Phi\left(\mathrm{C}_{2} \mathrm{H}_{4}\right)$ over a 500 -fold concentration range of $\mathrm{HI}$ indicates that all stable $\mathrm{C}_{2} \mathrm{H}_{3}$ radicals are intercepted by $\mathrm{HI}$ via the abstraction reaction

$$
\mathrm{C}_{2} \mathrm{H}_{3}+\mathrm{HI} \rightarrow \mathrm{C}_{2} \mathrm{H}_{4}+\mathrm{I} .
$$

On the assumption that the difference in $\Phi\left(\mathrm{C}_{2} \mathrm{H}_{4}\right)$ measured in the presence and absence of $\mathrm{HI}$ represents the contribution of reaction 3 to the ethylene formation, a value of $0.31 \pm 0.02$ is obtained for the quantum yield of stable vinyl radicals at $147 \mathrm{~nm}$ over the pressure range 1 to 22.6 torr.

The ethylene observed in the absence of HI can at least in part be accounted for by the decomposition of the internally excited $\mathrm{C}_{2} \mathrm{H}_{4} \mathrm{Cl}$ radicals formed in the reaction [12]

$$
\mathrm{H}+\mathrm{C}_{2} \mathrm{H}_{3} \mathrm{Cl} \rightarrow \mathrm{C}_{2} \mathrm{H}_{4} \mathrm{Cl}^{*} \rightarrow \mathrm{C}_{2} \mathrm{H}_{4}+\mathrm{Cl} .
$$

At pressures above 1 torr, $\Phi\left(\mathrm{C}_{2} \mathrm{H}_{4}\right)$ is essentially independent of the pressure of vinyl chloride, indicating that the $\mathrm{C}_{2} \mathrm{H}_{4} \mathrm{Cl}$ radicals must be highly excited. Apparently, the $\mathrm{C}_{2} \mathrm{H}_{4} \mathrm{Cl}$ are formed by addition of translationally excited $\mathrm{H}$ atoms to vinyl chloride. This is confirmed by the observation that addition of 100 torr of helium, which is an efficient remover of kinetic energy to 5.3 torr of vinyl chloride (table 2 ) reduces $\Phi\left(\mathrm{C}_{2} \mathrm{H}_{4}\right)$ nearly 10 -fold.

In principle, the quantum yield of $1,3-\mathrm{C}_{4} \mathrm{H}_{6}$ also provides a measure of the yield of $\mathrm{C}_{2} \mathrm{H}_{3}$. However, in a study of the $\mathrm{Hg}$ - sensitized photolysis of vinyl chloride, it was such that $\Phi\left(\mathrm{C}_{4} \mathrm{H}_{6}\right)$ diminishes rapidly with an increase in conversion (table 2). Furthermore there is evidence[13] that besides the recombination reaction

$$
\mathrm{CH}_{2} \mathrm{CH}+\mathrm{CH}_{2} \mathrm{CH} \rightarrow 1,3-\mathrm{C}_{4} \mathrm{H}_{6}
$$

the displacement reaction

$$
\mathrm{C}_{2} \mathrm{H}_{3}+\mathrm{C}_{2} \mathrm{H}_{3} \mathrm{Cl} \rightarrow 1,3-\mathrm{C}_{4} \mathrm{H}_{6}+\mathrm{Cl}
$$

should be considered as a source of 1,3- $\mathrm{C}_{4} \mathrm{H}_{6}$. Both reactions are quenched by the addition of $\mathrm{HI}$ (through interception of vinyl radicals in reaction 3) and by the addition of 2 percent oxygen to vinyl chloride (table 2 ).

At $147 \mathrm{~nm} \Phi\left(\mathrm{C}_{2} \mathrm{H}_{3}\right) / \Phi\left(\mathrm{C}_{2} \mathrm{H}_{2}\right)$ is nearly a factor of three lower than in the 190-220 nm photolysis, but this does not necessarily reflect a higher probability for the $\mathrm{HCl}$ elimination process 2 over the $\mathrm{C}-\mathrm{Cl}$ cleavage process 1 at higher photon energies. It may indeed be expected that at $147 \mathrm{~nm}$ a fraction of the internally excited $\mathrm{C}_{2} \mathrm{H}_{3}$ radicals formed in the $\mathrm{C}-\mathrm{Cl}$ cleavage process dissociate to give $\mathrm{C}_{2} \mathrm{H}_{2}$ as a product. The overall process

$$
\mathrm{C}_{2} \mathrm{H}_{3} \mathrm{Cl} \rightarrow \mathrm{C}_{2} \mathrm{H}_{2}+\mathrm{H}+\mathrm{Cl}
$$

requires only $5.5 \mathrm{eV}$, which is $2.9 \mathrm{eV}$ less than that available to the parent molecule absorbing a $147 \mathrm{~nm}$ $(8.4 \mathrm{eV})$ photon. There are actually a number of observations which are consistent with the occurrence of process 7. For instance, approximately 90 percent of the acetylene formed in the $147 \mathrm{~nm}$ photolysis of $\mathrm{CH}_{2} \mathrm{CDCl}$ consists of CHCD (table 6), as compared to only 50 percent at longer wavelengths $(\sim 200-220 \mathrm{~nm})$ [14]. At lower photon energies $(5.6-6.2 \mathrm{eV})$ there is barely enough energy for the occurrence of the overall process

$$
\mathrm{CH}_{2} \mathrm{CDCl} \rightarrow \mathrm{H}+\mathrm{C}_{2} \mathrm{HD}+\mathrm{Cl} \quad \Delta H=5.5 \mathrm{eV}
$$

and the high relative yield of $\mathrm{C}_{2} \mathrm{H}_{2}$ can definitely be ascribed to the elimination of $\mathrm{DCl}$ from a single carbon atom:

$$
\mathrm{CH}_{2} \mathrm{CDCl} \rightarrow \mathrm{C}_{2} \mathrm{H}_{2}+\text { DCl. }
$$

Formation of acetylene by decomposition of excited vinyl radicals is also indicated by the $\mathrm{C}_{2} \mathrm{H}_{3} \mathrm{Br}$ experiments (table 2) where the weaker carbon-halogen bond causes a drastic reduction in the quantum yield of stable vinyl radicals to about 0.04 as compared to 0.31 in the case of vinyl chloride. The data given in table 2 show that the lower yields of $\mathrm{C}_{2} \mathrm{H}_{3}$ radicals observed in the photolysis of $\mathrm{C}_{2} \mathrm{H}_{3} \mathrm{Br}$, compared to $\mathrm{C}_{2} \mathrm{H}_{3} \mathrm{Cl}$, is entirely compensated by an increase in the yield of $\mathrm{C}_{2} \mathrm{H}_{2}$. Finally, the $\mathrm{C}_{2} \mathrm{H}_{3} \mathrm{Cl}-\mathrm{HI}$ experiments given in table 3 demonstrate that an increase in the photon energy from $8.4 \mathrm{eV}$ to $10.0 \mathrm{eV}$ lowers the yield of $\mathrm{C}_{2} \mathrm{H}_{3}$ and increases that of $\mathrm{C}_{2} \mathrm{H}_{2}$. A primary process such as:

$$
\mathrm{C}_{2} \mathrm{H}_{3} \mathrm{Cl} \rightarrow \mathrm{C}_{2} \mathrm{H}_{2} \mathrm{Cl}+\mathrm{H}
$$


followed by decomposition of the $\mathrm{C}_{2} \mathrm{H}_{2} \mathrm{Cl}$ radical, should also be considered to account for these results. The net result of such a sequence is indistinguishable from process 1 followed by the dissociation of $\mathrm{C}_{2} \mathrm{H}_{3}$.

It is intriguing that stable $\mathrm{C}_{2} \mathrm{H}_{3}$ radicals are observed in the $147 \mathrm{~nm}$ photolysis of $\mathrm{C}_{2} \mathrm{H}_{3} \mathrm{Cl}$ while in the photolysis of $\mathrm{C}_{2} \mathrm{H}_{4}$ at the same wavelength, $\mathrm{C}_{2} \mathrm{H}_{3}$ radicals are essentially absent even though the overall process

$$
\mathrm{C}_{2} \mathrm{H}_{4} * \rightarrow \mathrm{C}_{2} \mathrm{H}_{2}+\mathrm{H}+\mathrm{H} \quad(\Phi=0.6)
$$

requires $6.4 \mathrm{eV}$ as compared to only $5.5 \mathrm{eV}$ for the analogous process 7 . Stable vinyl radicals are also absent in the $147 \mathrm{~nm}$ photolysis of $\mathrm{CH}_{2} \mathrm{CHF}$. The sum of the quantum yields of $\mathrm{C}_{2} \mathrm{H}_{2}(\sim 0.8)$ and $\mathrm{C}_{2} \mathrm{HF}(0.2)$ in the $\mathrm{O}_{2}$ scavenged photolysis of $\mathrm{C}_{2} \mathrm{H}_{3} \mathrm{~F}$ is equal to $\mathrm{l} \pm 0.05$ over the pressure range from 5 to 200 torr.

As already pointed out above, the low yield of $\mathrm{C}_{2} \mathrm{H}_{2}$ in the $\mathrm{CH}_{2} \mathrm{CDCl}$ experiments (table 6) indicates that elimnation of hydrogen chloride from a single carbon atom in vinyl chloride occurs only to a minor extent $[\Phi$ $\left.\left(\mathrm{C}_{2} \mathrm{H}_{2}\right) \sim 0.07\right]$ at $147 \mathrm{~nm}$. Furthermore, the quantum yield of $\mathrm{H}_{2}\left[\Phi\left(\mathrm{H}_{2}\right)=0.05\right]$ and $\mathrm{HD}[\Phi(\mathrm{HD})=0.01)$ in the photolysis of $\mathrm{CH}_{2} \mathrm{CDCl}$ at $147 \mathrm{~nm}$ shows that elimination of molecular hydrogen from vinyl chloride is even less probable. The latter is substantiated by the low yield of $\mathrm{C}_{2} \mathrm{HCl}(\Phi \sim 0.01)$ at $147 \mathrm{~nm}$. The low quantum yield of "molecular" $\mathrm{H}_{2}$ in vinyl chloride as compared to that reported in the photolysis of $\mathrm{C}_{2} \mathrm{H}_{4}\left[\Phi\left(\mathrm{H}_{2}\right)=0.4\right]$ can be attributed to the weak C-Cl bond strength or to localization of electronic excitation in that bond[15]

TABLE 3. Photolysis of vinyl chloride at $123.6 \mathrm{~nm}$

\begin{tabular}{c|c|c|c|c}
\hline \hline \multirow{2}{*}{$\begin{array}{c}\mathrm{CH}_{2} \mathrm{CDCl} \\
\text { pressure }\end{array}$} & $\begin{array}{c}\text { Additive } \\
\text { (torr) }\end{array}$ & $\begin{array}{c}\text { Photons } \\
\text { absorbed } \\
\times 10^{15}\end{array}$ & Acetylene & Ethylene \\
\cline { 3 - 5 } & & 35 & 0.82 & 0.175 \\
& & 30 & .83 & .093 \\
1.1 & $\ldots \ldots \ldots \ldots \ldots \ldots$ & .87 & .072 \\
1.1 & $\mathrm{NO}-0.3$ & 30 & .84 & .044 \\
1.1 & $\mathrm{NO}-2.1$ & 30 & .84 & .107 \\
1.1 & $\mathrm{NO}-5.0$ & 30 & .86 & .166 \\
5.3 & $\mathrm{O}_{2}-0.3$ & 20 & .87 & .174 \\
5.3 & $\mathrm{HI}-0.2$ & 20 & .87 & .174 \\
5.3 & $\mathrm{HI}-1.6$ & 20 & .86 & .120 \\
5.3 & $\mathrm{HI}-5.3$ & 70 & \multicolumn{2}{|c}{} \\
24.0 & $\ldots \ldots \ldots \ldots \ldots \ldots \ldots \ldots \ldots$ &
\end{tabular}

\subsection{Photolysis in the Photoionization Region}

The photon energies corresponding to the krypton $(10 \mathrm{eV})$ and argon (11.6-11.8 eV) resonance lines are above the photoionization threshold of vinyl chloride $(9.99 \mathrm{eV})$ and vinyl bromide $(9.8 \mathrm{eV})$. Because the photoionization quantum yields $\left(\Phi_{+}\right)$are below unity (table 1 ), dissociation of superexcited vinyl halide molecules will occur over the 10-11.8 eV photon energy range. The quantum yield of the superexcited molecules which do not autoionize is simply given by $\left(1-\Phi_{+}\right)$.

In order to derive information concerning the primary modes of decomposition of the superexcited molecules from an analysis of the final products formed, one has to substract out the yields of products formed in unimolecular and bimolecular ionic processes. For the wavelength range covered here $(10 \mathrm{eV}-11.8 \mathrm{eV})$, this is relatively simple in view of the fact that the parent ion is the only reactive primary ion in the system. The threshold for the formation of the vinyl ion, which is the major fragment ion observed in the $70 \mathrm{eV}$ mass spectrum of the vinyl halides, is $12.5 \mathrm{eV}$ and $12 \mathrm{eV}$ for vinyl chloride and vinyl bromide respectively $[4,16]$.

On the basis of the high rate for disappearance of the parent ion reported in two recent low pressure mass spectrometric studies [17-18] it can be concluded that under our experimental conditions neutralization of the parent ion is to be ruled out. Instead the vinyl halide ion will react with its neutral counterpart to yield product ions such as $\mathrm{C}_{4} \mathrm{H}_{6} \mathrm{Cl}^{+}, \mathrm{C}_{4} \mathrm{H}_{5} \mathrm{Cl}^{+}$and $\mathrm{C}_{3} \mathrm{H}_{4} \mathrm{Cl}^{+}$. The relative abundances of these ions which are formed in a relatively long lived collision complex are dependent on the internal energy content of the parent ion. It has also been shown that these product ions react further with vinyl chloride to form higher molecular weight ions. Several of these reactions occur with the explusion of $\mathrm{HCl}$ as a neutral unity and it can be surmised that they account in part for the high $G$-value of $\mathrm{HCl}$ observed [2] in the gas phase radiolysis of vinyl chloride $(G(\mathrm{HCl}) \sim 10)$.

From the foregoing it can be expected that at $10 \mathrm{eV}$ and 11.6-11.8 eV only the dissociation of neutral excited molecules will contribute to the formation of the major hydrocarbon product, acetylene. There is strong support for this view in that, in the argon resonance photolysis experiments, the quantum yield of ionization plus the yield of acetylene $\left(\Phi\left(\mathrm{C}_{2} \mathrm{H}_{2}\right)+\Phi_{+}\right)$is approximately equal to unity for both vinyl chloride and vinyl

TABle 4. Photolysis of vinyl chloride and vinyl bromide at 104.8$106.7 \mathrm{~nm}$

\begin{tabular}{c|c|c|c|c|}
\hline \hline \multirow{2}{*}{$\begin{array}{c}\mathrm{C}_{2} \mathrm{H}_{3} \mathrm{X} \\
\text { pressure }\end{array}$} & \multirow{2}{*}{$\begin{array}{c}\text { Additive } \\
\text { (torr) }\end{array}$} & $\begin{array}{c}\text { Photons } \\
\text { absorbed } \\
\text { x1015 }\end{array}$ & Acetylene & Ethylene \\
\cline { 4 - 5 } & & & & \multicolumn{2}{|c}{ Quantum yields } \\
\hline $\begin{array}{c}\text { Vinyl chloride } \\
0.5\end{array}$ & - & 2 & 0.51 & 0.093 \\
1.2 & - & 2 & .50 & .095 \\
5.3 & - & 2 & .51 & .099 \\
5.3 & $\mathrm{HI}-0.5$ & 3 & .49 & .125 \\
5.3 & $\mathrm{HI}-1.6$ & 3 & .49 & .137 \\
& & & & \\
Vinyl bromide & & 3 & .34 & .110 \\
1.0 & - & 3 & .35 & .092 \\
5.6 & - & 3 & .35 & .190 \\
5.6 & $\mathrm{HI}-0.2$ & &
\end{tabular}

bromide (table 4). The $\mathrm{HI}$ additive experiments given in table 4 indicate that stable vinyl radicals are apparently formed with a relatively low quantum yield at 1048$67 \AA\left(\Phi\left(\mathrm{C}_{2} \mathrm{H}_{3}\right)<0.04\right)$. At $10 \mathrm{eV}, \Phi\left(\mathrm{C}_{2} \mathrm{H}_{3}\right)$ can be estimated to be 0.06 . The actual primary dissociative processes responsible for the formation of acetylene cannot be ascertained from the present results. The isotopic analysis of the ethylene product formed in the photolysis of $\mathrm{CH}_{2} \mathrm{CDCl}$ does however indicate that the reaction

$$
D^{*}+\mathrm{CH}_{2} \mathrm{CDCl} \rightarrow \mathrm{C}_{2} \mathrm{H}_{2} \mathrm{D}_{2}+\mathrm{Cl}
$$


(where $\mathrm{D}^{*}$ represents a $\mathrm{D}$ atom with excess translational energy) increases in importance with increase in photon energy. This points to the increased importance of the overall process

$$
\mathrm{CH}_{2} \mathrm{CDCl}+h \nu \rightarrow \mathrm{C}_{2} \mathrm{H}_{2}+\mathrm{D}+\mathrm{Cl}
$$

as a function of energy. Also, the fractional yield of $\mathrm{C}_{2} \mathrm{H}_{2}$ in the acetylene increases gradually from 8.4 to $11.6-11.8 \mathrm{eV}$ (table 6). Process 13 can be looked upon as the elimination of excited DCl (process 9) or the cleavage of the C-D bond in the superexcited vinyl chloride molecule followed by decomposition of the internally excited $\mathrm{C}_{2} \mathrm{H}_{2} \mathrm{Cl}$ radical. The latter is a mechanism which is more probable in view of the fact that a sharp drop is noted in the abundance of process 9 from $200-220$ to $147 \mathrm{~nm}$.

\subsection{Radiolysis}

There is experimental evidence which indicates that polymerization in gaseous vinyl chloride proceeds via a free radical as well as an ionic reaction mechanism [2]. Radicals formed in the decomposition of neutral excited vinyl chloride molecules, parent ions and their main dissociation fragments $\left(\mathrm{C}_{2} \mathrm{H}_{3}^{+}, \mathrm{Cl}\right)$ have to be considered as potential chain initiators. In the light of what we learned about the primary dissociative processes in neutral excited vinyl chloride an examination of the data given in tables 5 and 6 provides quantitative information about the yields and sources of the reactive species formed in the gas phase radiolysis.

TABLE 5. Radiolysis of vinyl chloride

\begin{tabular}{|c|c|c|c|c|}
\hline \multirow{2}{*}{$\begin{array}{c}\mathrm{CH}_{2} \mathrm{CDCl} \\
\text { pressure }\end{array}$} & \multirow{2}{*}{$\begin{array}{l}\text { Additive } \\
\text { (torr) }\end{array}$} & \multirow{2}{*}{$\begin{array}{c}\text { Dose } \\
\mathrm{eV} / \mathrm{g} \\
\times 10^{-22}\end{array}$} & Acetylene & Ethylene \\
\hline & & & \multicolumn{2}{|c|}{$G$-values ${ }^{\text {a }}$} \\
\hline 28.7 & & 2 & 1.52 & 0.254 \\
\hline 28.7 & & 6 & 1.50 & .275 \\
\hline 28.7 & & 24 & 1.48 & .326 \\
\hline 28.7 & $\mathrm{HI}-1.15$ & 2 & 1.56 & .479 \\
\hline 85.2 & & 2 & 1.47 & .234 \\
\hline 196.3 & & 2 & 1.36 & .221 \\
\hline
\end{tabular}

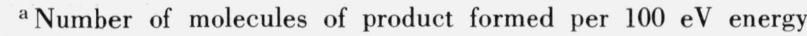
absorbed.

The only major reactive entity which is present, in addition to those already considered in the 104.8-106.7 $\mathrm{nm}$ photolysis, is the $\mathrm{C}_{2} \mathrm{H}_{3}^{+}$ion formed in the fragmentation process

$\mathrm{C}_{2} \mathrm{H}_{3} \mathrm{Cl}^{+} \rightarrow \mathrm{C}_{2} \mathrm{H}_{3}^{+}+\mathrm{Cl}$ (appearance potential $12.5 \mathrm{eV}$ ).

Ion pair formation may also contribute to the formation of $\mathrm{C}_{2} \mathrm{H}_{3}^{+}$

$$
\mathrm{C}_{2} \mathrm{H}_{3} \mathrm{Cl}+e \rightarrow \mathrm{C}_{2} \mathrm{H}_{3}^{+}+\mathrm{Cl}^{-}+e
$$

but is apparently of minor importance [16].
TABLE 6. Isotopic composition of the acetylene and ethylene in the Photolysis and radiolysis of $\mathrm{CH}_{2} \mathrm{CDCl}$

\begin{tabular}{c|c|c|r|r|r|r}
\hline \hline \multirow{2}{*}{ Radiation } & $\mathrm{CH}_{2} \mathrm{CDCl}$ & Additive & $\mathrm{C}_{2} \mathrm{H}_{2} \mathrm{D}_{2}$ & $\mathrm{C}_{2} \mathrm{H}_{3} \mathrm{D}$ & $\mathrm{C}_{2} \mathrm{HD}$ & $\mathrm{C}_{2} \mathrm{H}_{2}$ \\
\cline { 4 - 7 } & pressure & (torr) & \multicolumn{5}{|c}{ Relative yields } \\
\hline $200-220 \mathrm{~nm}^{\mathrm{a}}$ & 5.0 & - & & & 100 & 100 \\
$147 \mathrm{~nm}$ & 5.3 & - & 9.5 & 100 & 100 & 13.5 \\
& 5.3 & $\mathrm{HI}-0.2$ & 2.8 & 100 & 100 & 13.3 \\
$123.6 \mathrm{~nm}$ & 5.3 & - & 16.2 & 100 & 100 & 22.0 \\
& 5.3 & $\mathrm{HI}-0.2$ & 10.0 & 100 & & \\
$104.8-106.7 \mathrm{~nm}$ & 5.3 & - & 27.5 & 100 & 100 & 31.0 \\
& 5.3 & $\mathrm{HI}-0.2$ & 24.0 & 100 & 100 & 32.0 \\
$\gamma$-ray & 28.7 & - & 27.4 & 100 & 100 & 40.5 \\
& 183.0 & - & 17.0 & 100 & 100 & 37.3 \\
\hline
\end{tabular}

${ }^{a}$ M.H.J. Wijnen, unpublished results.

Mass spectrometric investigations [17-18] have shown that the $\mathrm{C}_{2} \mathrm{H}_{3}^{+}$ion reacts with vinyl chloride in the following manner

$$
\begin{aligned}
\mathrm{C}_{2} \mathrm{H}_{3}^{+}+\mathrm{C}_{2} \mathrm{H}_{3} \mathrm{Cl} & \rightarrow \mathrm{C}_{2} \mathrm{H}_{4} \mathrm{Cl}^{+}+\mathrm{C}_{2} \mathrm{H}_{2} \\
k= & 5.6 \times 10^{-10} \mathrm{~cm}^{3} \text { molecule }{ }^{-1} \mathrm{~s}^{-1} \\
& \rightarrow \mathrm{C}_{4} \mathrm{H}_{5}^{+}+\mathrm{HCl} \\
k & =1.5 \times 10^{-10} \mathrm{~cm}^{3} \text { molecule }{ }^{-1} \mathrm{~s}^{-1} .
\end{aligned}
$$

Experiments carried out in the NBS photoionization mass spectrometer [19] confirm the occurrence of these reaction channels and show that in the case of $\mathrm{CH}_{2} \mathrm{CDCl}$ the $\mathrm{C}_{2} \mathrm{H}_{2} \mathrm{D}^{+}$ions react to give both $\mathrm{C}_{2} \mathrm{H}_{2}$ $(30 \%)$ and $\mathrm{C}_{2} \mathrm{HD}(70 \%)$ as ñeutral products

$$
\begin{aligned}
\mathrm{C}_{2} \mathrm{H}_{2} \mathrm{D}^{+}+\mathrm{CH}_{2} \mathrm{CDCl} & \rightarrow \mathrm{C}_{2} \mathrm{H}_{2} \mathrm{D}_{2} \mathrm{Cl}^{+}+\mathrm{C}_{2} \mathrm{H}_{2} \\
& \rightarrow \mathrm{C}_{2} \mathrm{H}_{3} \mathrm{DCl}+\mathrm{C}_{2} \mathrm{HD} .
\end{aligned}
$$

In order to estimate $G\left(\mathrm{C}_{2} \mathrm{H}_{2} \mathrm{D}^{+}\right)$in the gas phase radiolysis of $\mathrm{CH}_{2} \mathrm{CDCl}, i-\mathrm{C}_{4} \mathrm{D}_{10}$ was added as a vinyl ion interceptor. Vinyl ions would contribute to the formation of $\mathrm{C}_{2} \mathrm{H}_{2} \mathrm{D}_{2}$ via the $\mathrm{D}^{-}$transfer reaction [20]:

$$
\begin{aligned}
& \mathrm{C}_{2} \mathrm{H}_{2} \mathrm{D}^{+}+i-\mathrm{C}_{4} \mathrm{D}_{10} \rightarrow \mathrm{C}_{2} \mathrm{H}_{2} \mathrm{D}_{2}+\mathrm{C}_{4} \mathrm{D}_{9}^{+} \\
& k=11.4 \times 10^{-10} \mathrm{~cm}^{3} \text { molecule }{ }^{-1} \mathrm{~s}^{-1} .
\end{aligned}
$$

From the rate constants for the individual reactions, it can be calculated that at the highest concentration of $i$ - $\mathrm{C}_{4} \mathrm{D}_{10}$ (table 7 ) approximately 75 percent of the vinyl

TABLE 7. Radiolysis of $\mathrm{CH}_{2} \mathrm{CDCl}-i-\mathrm{C}_{4} \mathrm{D}_{10}$ mixtures

\begin{tabular}{c|c|c|c|c|c}
\hline \hline \multirow{2}{*}{$\begin{array}{c}\mathrm{CH}_{2} \mathrm{CDCl} \\
\text { pressure }\end{array}$} & \multirow{2}{*}{$\begin{array}{c}i \text { - } \mathrm{C}_{4} \mathrm{D}_{10} \\
\text { (torr) }\end{array}$} & $\mathrm{C}_{2} \mathrm{DH}_{3}$ & $\mathrm{C}_{2} \mathrm{D}_{2} \mathrm{H}_{2}$ & $\mathrm{C}_{2} \mathrm{HD}$ & $\mathrm{C}_{2} \mathrm{H}_{2}$ \\
\cline { 3 - 6 } & & \multicolumn{4}{|c}{$G_{\mathrm{CH}_{2} \mathrm{CDCl}}{ }^{\text {a }}$} \\
\hline 28.7 & $\ldots \ldots \ldots \ldots$ & 0.11 & 0.06 & 1.06 & 0.44 \\
28.7 & 14.4 & .10 & .17 & 1.07 & .42 \\
28.7 & 28.7 & .09 & .22 & 1.06 & .44 \\
28.7 & 56.5 & .08 & .27 & 1.08 & .44 \\
\hline
\end{tabular}

a Number of molecules per $100 \mathrm{eV}$ absorbed by vinyl chloride. 
ions should be intercepted. It follows from the $G\left(\mathrm{C}_{2} \mathrm{H}_{2} \mathrm{D}_{2}\right)$ values given in table 7 that $G\left(\mathrm{C}_{2} \mathrm{H}_{2} \mathrm{D}^{+}\right)=$ $0.28-0.36$. The lower value applies if one assumes that reaction 12 resulting in the formation of $\mathrm{C}_{2} \mathrm{H}_{2} \mathrm{D}_{2}$ in the absence of $i-\mathrm{C}_{4} \mathrm{D}_{10}$ is not affected by the presence of $i-\mathrm{C}_{4} \mathrm{D}_{10}$.

The yield of $\mathrm{C}_{2} \mathrm{H}_{2} \mathrm{D}^{+}$in the radiolysis is well below the value one would estimate from the $70 \mathrm{eV}$ mass spectral cracking pattern of vinyl chloride. Apparently, because of the short time interval between collisions in the radiolysis experiments the parent ion may be collisionally deactivated or react before dissociating. A variation in pressure also affects the mode of reaction of the vinyl ion with vinyl chloride. If indeed the proton transfer reaction were the main reaction channel under these conditions, then contrary to the data given in table 7 , a decrease of $G\left(\mathrm{C}_{2} \mathrm{HD}\right)$ and $G\left(\mathrm{C}_{2} \mathrm{H}_{2}\right)$ should be observed when the fraction of $\mathrm{C}_{2} \mathrm{H}_{2} \mathrm{D}^{+}$ intercepted by $i-\mathrm{C}_{4} \mathrm{D}_{10}$ increases. The apparent nonoccurrence of reactions 18 and 19 under the radiolysis conditions indicates that these reactions occur via a long lived complex which can be collisionally deactivated, favoring a condensation type reaction such as 17. There is evidence in the literature [21] to show that if for a particular reactant pair, proton transfer competes with condensation reaction, the latter will be favored at low kinetic or internal energy.

Because neither the parent ion (see previous section) nor the vinyl ion contributes to the formation of acetylene as a neutral product in the radiolysis it follows that only the decomposition of neutral excited vinyl chloride and the fast charge transfer reaction

$$
\mathrm{C}_{2} \mathrm{H}_{2}^{+}+\mathrm{C}_{2} \mathrm{H}_{3} \mathrm{Cl} \rightarrow \mathrm{C}_{2} \mathrm{H}_{2}+\mathrm{C}_{2} \mathrm{H}_{3} \mathrm{Cl}^{+}
$$

are plausible modes of acetylene formation. Upon addition of $i-\mathrm{C}_{4} \mathrm{D}_{10}$ reaction 21 would compete with

$$
\mathrm{C}_{2} \mathrm{H}_{2}^{+}+i-\mathrm{C}_{4} \mathrm{D}_{10} \rightarrow \mathrm{C}_{2} \mathrm{H}_{2}+\mathrm{C}_{4} \mathrm{D}_{10}^{+}
$$

so that there would be no net change in $G$ (acetylene). However, in the $70 \mathrm{eV}$ mass spectrum of $\mathrm{C}_{2} \mathrm{H}_{3} \mathrm{Cl}$, $\mathrm{C}_{2} \mathrm{H}_{2}^{+}$is only 10 percent of the total ionization $(G=0.4)$. Furthermore, in view of its high appearance potential $(13.8 \mathrm{eV})$ as compared to that of $\mathrm{C}_{2} \mathrm{H}_{3}^{+}(12.8 \mathrm{eV})$ one may expect the yield of this fragment to be diminished even more at high pressure than $\mathrm{C}_{2} \mathrm{H}_{3}^{+}$. It is reasonable therefore to assume that acetylene coming from the $\mathrm{C}_{2} \mathrm{H}^{+}$ion has a yield smaller than 0.4 . By elimination, we conclude that fragmentation of neutral excited vinyl chloride accounts for most of the observed acetylene, $G \sim 1.2-1.4$.

The increment in $G\left(\mathrm{C}_{2} \mathrm{H}_{4}\right)$ upon addition of $\mathrm{HI}$ to $\mathrm{C}_{2} \mathrm{H}_{3} \mathrm{Cl}$ provides an approximate value of $0.25 \pm 0.05$ for $G\left(\mathrm{C}_{2} \mathrm{H}_{3}\right)$ which can be entirely ascribed to process 1 , the dissociation of the neutral excited molecule. The low yield of $\mathrm{C}_{2} \mathrm{H}_{3}$ relative to that of $\mathrm{C}_{2} \mathrm{H}_{2}$ is consistent with the photolysis experiments. Although the optical excitation spectrum of vinyl chloride is not known, if one takes other organic molecules as examples [22] it may be expected that a considerable fraction of the excitation occurs in the ionization region. Comparison of the isotopic analysis of the acetylene and ethylene formed in the radiolysis of $\mathrm{CH}_{2} \mathrm{CDCl}$ with those observed in the photolysis substantiates this view (table 6). Summation of the yield of acetylene not accounted for by reaction 21 and of the vinyl radicals gives a $G$-values of $1.55 \pm 0.1$ of neutral excited molecules in the gas phase radiolysis. That is, the ratio of neutral excited molecule formation to ionization in the radiolysis of vinyl chloride is 0.39 .

\section{References}

[1] Chapiro, A., Radiation Chemistry of Polymeric Systems, Interscience, New York (1962).

[2] Grossoleil, J., and Herman, J. A., Can. J. Chem. 49,363 (1971) and references cited therein.

[3] Fujimoto, T., Rennert, A. M., and Wijnen, M. H. J., Ber. Bunsenges. Physik Chem. 74, 282 (1970).

[4] Franklin, J. L., Dillard, J. G., Rosenstock, H. M., Herron, J. T., Draxl, K., and Field, F. H., Ionization Potentials, Appearance Potentials and Heats of Formation of Gaseous Positive Ions, Nat. Stand. Ref. Data Ser., Nat. Bur. Stand. (U.S.) 26, 289 pages (1969)

[5] Gorden, R., Jr., Rebbert, R. E., and Ausloos, P., Nat. Bur. Stand. (U.S.), Tech. Note 496, 55 pages (1969).

[6] Yang, J. Y., and Servedio, F. M., Can. J. Chem. 46, 338 (1968).

[7] Ausloos, P., unpublished results.

[8] Potzinger, P., Glasgow, L. C., and von Bunau, G., Z. Naturforsch. 27 a, 628 (1972).

[9] Gorden, R., Jr., and Ausloos, P., J. Chem. Phys. 47, 1799 (1967).

[10] Watanabe, K., Matsunage, F. M., and Sakai, H., Appl. Opt. 6, 391 (1967)

[11] Leblanc, R. M., and Herman, J. A., J. de Chim. Phys. 63, 1055 (1966).

[12] Rennert, A. M., and Wijnen, M. H. J., Ber Bunsenges. Physik. Chem. 72, 222 (1968).

[13] Bellas, M. G., Wan, J. K. S., Allen, W. F., Strausz, O. P., and Gunning, H. E., J. Phys. Chem. 68, 2170 (1964).

[14] Wijnen, M. H. J., to be published.

[15] Walsh, A. D., Trans. Faraday Soc. 41, 35 (1945).

[16] Lossing, F. P., Can. J. Chem. 49, 357 (1971).

[17] Herman, J. A., Myher, J. J., and Harrison, A. G., Can. J. Chem. 47, 647 (1969).

[18] Hughes, B. M., Tiernan, T. O., and Futrell, J. H., J. Phys. Chem. 73, 829 (1969).

[19] Sieck, L. W., Searles, S. K., and Ausloos, P., J. Amer. Chem. Soc. 91, 7627 (1969).

[20] Munson, M. S. B., J. Phys. Chem. 71, 3966 (1967).

[21] Sieck, L. W., and Ausloos, P., J. Res. Nat. Bur. Stand. (U.S.), 76A (Phys. and Chem.), No. 3, 253-262 (1972).

[22] Platzman, R. L., Radiation Research, Siline, G., Editor (NorthHolland Publishing Co.) (1967), p. 20.

(Paper 77A2-767) 